\title{
NUMERICAL INVESTIGATION OF ONE SOBOLEV TYPE MATHEMATICAL MODEL
}

A.A. Zamyshlyaeva ${ }^{1}$, alzama@mail.ru, S.V. Surovtsev ${ }^{1}$, ssw-92@ya.ru.

${ }^{1}$ South Ural State University, Chelyabinsk, Russian Federation.

The article is devoted to a numerical investigation of the Boussinesq - Lòve mathematical model. Algorithm for finding of the numerical solution to the Cauchy Dirichlet problem for the Boussinesq - Lòve equation modeling longitudinal oscillations in a thin elastic rod with regard to transverse inertia was obtained on the basis of a phase space method and by using a finite differences method. This problem can be reduced to the Cauchy problem for the Sobolev type equation of the second order, which is not solvable for arbitrary initial values. The constructed algorithm includes the additional check if initial data belongs to the phase space. The algorithm is implemented as a program in Matlab. The results of numerical experiments are obtained both in regular and degenerate cases. The graphs of obtained solutions are presented in each case.

Keywords: Boussinesq - Lòve equation; Cauchy - Dirichlet problem; finite differences method; Sobolev type equation; phase space; conditions of data consistency; system of difference equations; the Thomas algorithm.

\section{Introduction}

Consider Boussinesq - Lòve equation

$$
(\lambda-\Delta) u_{t t}=\alpha\left(\lambda^{\prime}-\Delta\right) u_{t}+\beta\left(\lambda^{\prime \prime}-\Delta\right) u, \quad 0<x<\pi, \quad t>0
$$

with initial

$$
\begin{aligned}
u(x, 0)=\varphi(x), & 0<x<\pi, \\
u_{t}(x, 0)=\psi(x), & 0<x<\pi,
\end{aligned}
$$

and boundary

$$
u(0, t)=u(\pi, t)=0, \quad t>0
$$

conditions. The functions $\varphi, \psi$ are given, $u=u(x, t)$ is unknown function, $\Delta=\frac{\partial^{2}}{\partial x^{2}}$ is one-dimensional Laplace operator. Mathematical model (1) - (3) describes longitudinal oscillations in an elastic rod with inertia [1]. Problem (1) - (3) was studied by Zamyshlyaeva A.A. [2] and her students [3-5]. Algorithm of numerical solution of problem (1) - (3) based on modified Galerkin method was constructed in [6].

Mathematical model (1) - (3) can be reduced to the Cauchy problem

$$
u(0)=\varphi, \quad \dot{u}(0)=\psi
$$

for operator-differential equation

$$
A \ddot{u}=B_{1} \dot{u}+B_{0} u \text {. }
$$

If operator $A$ is continuously inversible, then equation (5) is called non-degenerate or regular. Otherwise, in particular when $\operatorname{ker} A \neq\{0\}$, such equation is called a Sobolev 
type equation. It is well-known that the Cauchy problem for Sobolev type equation is not solvable with arbitrary initial values. In our opinion, the most productive approach to the study of these equations is the phase space method. Its foundations were laid by G.A. Sviridyuk and T.G. Sukacheva [7] in the study of semilinear Sobolev type equations of the first order.

Concerning (1) - (3) there were considered [6] three cases depending on parametres $\lambda, \lambda^{\prime}, \lambda^{\prime \prime}$. In the cases when $\lambda \notin \sigma(\Delta)$ and $(\lambda \in \sigma(\Delta)) \wedge\left(\lambda=\lambda^{\prime} \neq \lambda^{\prime \prime}\right)$ the phase space of equation (1) was constructed and this confirms results [2]. In the case $(\lambda \in \sigma(\Delta)) \wedge\left(\lambda \neq \lambda^{\prime}\right)$, that was eliminated in [2], we have the necessary conditions for the unique solvability of $(1)-(3)$ in the form of dependence of functions $\varphi(x)$ and $\psi(x)$, so it is shown that the phase space in the sense of [2] doesn't exist.

\section{Approximate Solution of the Problem}

In this investigation we present the approximate solution to (1) - (3) that is constructed by using a finite differences method. Construct a net over the whole surface of the rectangle $(0, \pi) \times(0, T)$

$$
x_{i}=h \cdot i, i=\overline{0, N}, h=\frac{\pi}{N}, t_{j}=\tau \cdot j, j=\overline{0, M}, \tau=\frac{T}{M}
$$

and define the grid function

$$
u_{i, j}=u\left(x_{i}, t_{j}\right), i=\overline{0, N}, j=\overline{0, M} .
$$

Then

$$
u_{t}\left(x_{i}, t_{j}\right)=\frac{u_{i, j+1}-u_{i, j-1}}{2 \tau}
$$

the second derivative of $t$ :

$$
u_{t t}\left(x_{i}, t_{j}\right)=\frac{u_{i, j+1}-2 u_{i, j}+u_{i, j-1}}{\tau^{2}},
$$

the second derivative of $x$ :

$$
u_{x x}\left(x_{i}, t_{j}\right)=\frac{u_{i+1, j}-2 u_{i, j}+u_{i-1, j}}{h^{2}}
$$

$i=\overline{2, N-1}, j=\overline{2, M-1}$.

If we substitute $(6)-(8)$ in to (1) and combine like terms, we get:

$$
\begin{gathered}
u_{i+1, j+1}\left(-\frac{1}{\tau^{2} \cdot h^{2}}-\frac{\alpha}{2 \tau \cdot h^{2}}\right)+u_{i, j+1}\left(\frac{\lambda}{\tau^{2}}+\frac{2}{\tau^{2} \cdot h^{2}}+\frac{\alpha \lambda^{\prime}}{2 \tau}+\frac{2 \alpha}{2 \tau \cdot h^{2}}\right)+ \\
+u_{i-1, j+1}\left(-\frac{1}{\tau^{2} \cdot h^{2}}-\frac{\alpha}{2 \tau \cdot h^{2}}\right)+u_{i+1, j}\left(\frac{2}{\tau^{2} \cdot h^{2}}-\frac{\beta}{h^{2}}\right)+ \\
+u_{i, j}\left(-\frac{2 \lambda}{\tau^{2}}-\frac{4}{\tau^{2} \cdot h^{2}}+\beta \lambda^{\prime \prime}+\frac{2 \beta}{h^{2}}\right)+u_{i-1, j}\left(\frac{2}{\tau^{2} \cdot h^{2}}-\frac{\beta}{h^{2}}\right)+ \\
+u_{i+1, j-1}\left(-\frac{1}{\tau^{2} \cdot h^{2}}+\frac{\alpha}{2 \tau \cdot h^{2}}\right)+u_{i, j-1}\left(\frac{\lambda}{\tau^{2}}+\frac{2}{\tau^{2} \cdot h^{2}}-\frac{\alpha \lambda^{\prime}}{2 \tau}-\frac{2 \alpha}{2 \tau \cdot h^{2}}\right)+ \\
+u_{i-1, j-1}\left(-\frac{1}{\tau^{2} \cdot h^{2}}+\frac{\alpha}{2 \tau \cdot h^{2}}\right)=0,
\end{gathered}
$$

where $i=\overline{2, N-1}, j=\overline{2, M-1}$. Futher, fix $j$ and solve the resultant system of equations for $(j+1)$-th layer on $t$ by a Thomas algorithm. 


\section{Algorithm Description}

Describe the algorithm in detail. There is one step for every block of algorithm.

Step 1. After the start of program execution it is necessary to input coefficients $\lambda, \lambda^{\prime}, \lambda^{\prime \prime}, \alpha, \beta$, functions $\varphi(x)$ and $\psi(x)$, length of segment for solvability and time interval $t \in[0, T]$, the number of $t$ and $x$ partitions.

Step 2. Generate searching unknown approximate solution $U$ in loop from 2 to $M-1$ and in inner loop from 2 to $N-1$ by the finite differences scheme.

Step 3. Conditional test if $\lambda$ belongs to Laplace operator spectrum, i.e. if $\lambda$ can be represented as $-k^{2}$.

If step 3 has a true value:

Step 4. Conditional test if $\lambda=\lambda_{1}$.

If step 4 has a true value:

Step 5. Conditional test from [6] for initial conditions, i.e. if $\left(u_{0}, \varphi_{k}\right)=0$ and $\left(u_{0}, \psi_{k}\right)=0$.

Futher, step 9.

If step 4 has a false value:

Step 6. Conditional test from [6] for initial conditions, i.e. if $\left(u_{0}, \varphi_{k}\right)=\left(u_{0}, \psi_{k}\right) / \mu_{k}$, where $\mu_{k}$ is a characteristic equation root for Boussinesq - Lòve equation (1).

Futher, step 9.

If step 5 has a false value:

Step \%. In accordance with condition the program generates a message that there are no solutions.

If step 6 has a false value:

Step 8. In accordance with condition the program generates a message that there are no solutions.

If step 5 and step 6 have a true value and step 3 has a false value:

Step 9. Generate a system of linear equations in loop from 2 to $M-1$.

Step 10. Resultant system is solved by a Thomas algorithm in unknown coefficients $u_{i j}$.

Step 11. Resultant solution is displayed by a graph.

The block diagram of the program is shown on fig 1 .

\section{Experimental Examples}

Example 1. Consider the mathematical model

$$
\left\{\begin{array}{l}
(\lambda-\Delta) u_{t t}=\alpha\left(\Delta-\lambda^{\prime}\right) u_{t}+\beta\left(\Delta-\lambda^{\prime \prime}\right) u, \\
u(x, 0)=\sin (x), u_{t}(x, 0)=\sin (x)+\sin (2 x), \\
u(0, t)=u(\pi, t)=0 .
\end{array}\right.
$$

with parametres $\alpha=-1, \beta=-1, \lambda=2, \lambda^{\prime}=-1, \lambda^{\prime \prime}=3$, the amount of steps for $x: N=40$, for $t: M=60$. This mathematical model is non-degenerate, therefore the solution exists. The graph of solution is shown on fig. 2 .

Example 2. Consider the mathematical model

$$
\left\{\begin{array}{l}
(\lambda-\Delta) u_{t t}=\alpha\left(\Delta-\lambda^{\prime}\right) u_{t}+\beta\left(\Delta-\lambda^{\prime \prime}\right) u \\
u(x, 0)=\sin (x), u_{t}(x, 0)=\sin (x)+\sin (2 x), \\
u(0, t)=u(\pi, t)=0
\end{array}\right.
$$




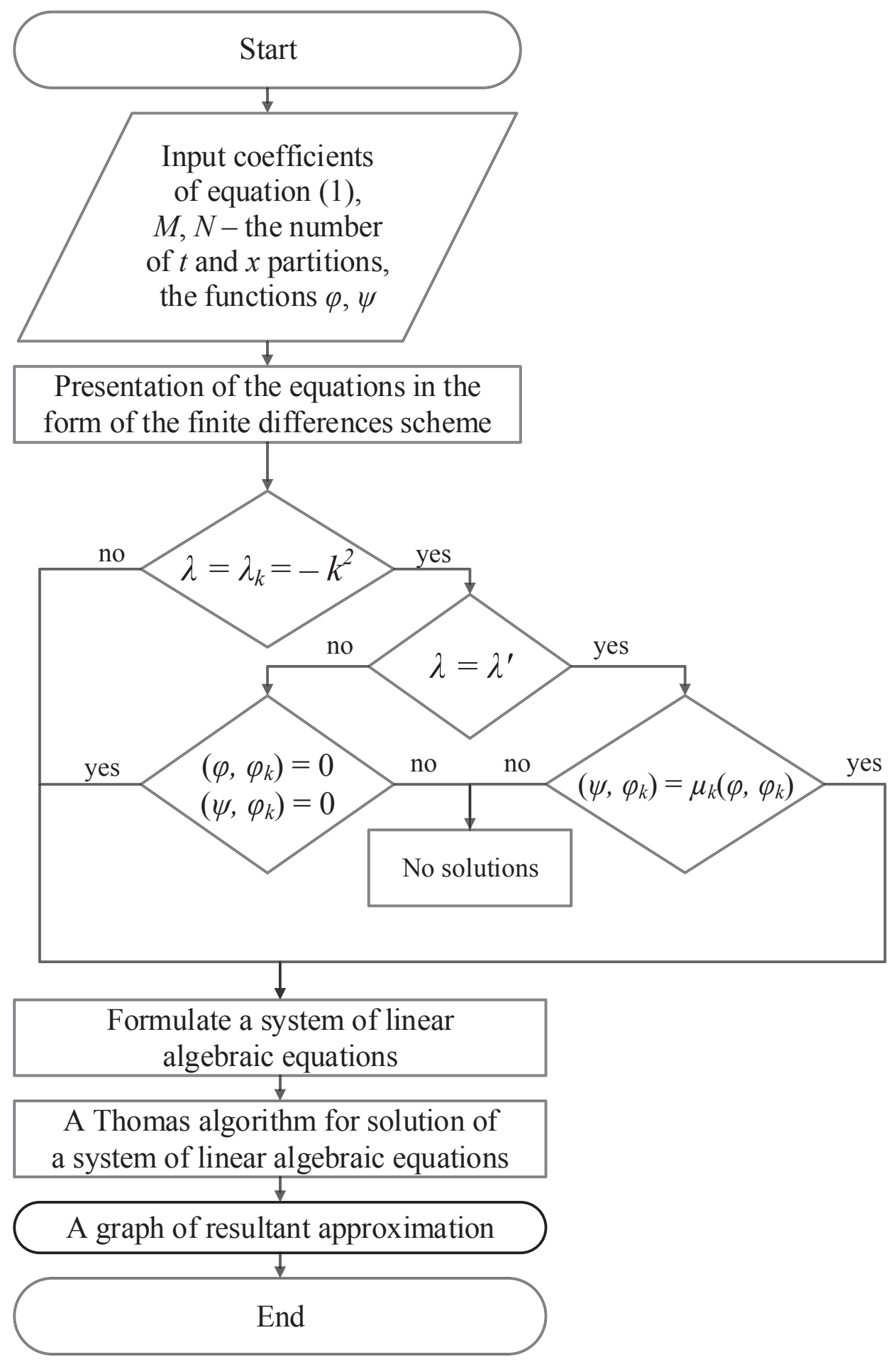

Fig. 1. The block diagram of the program 


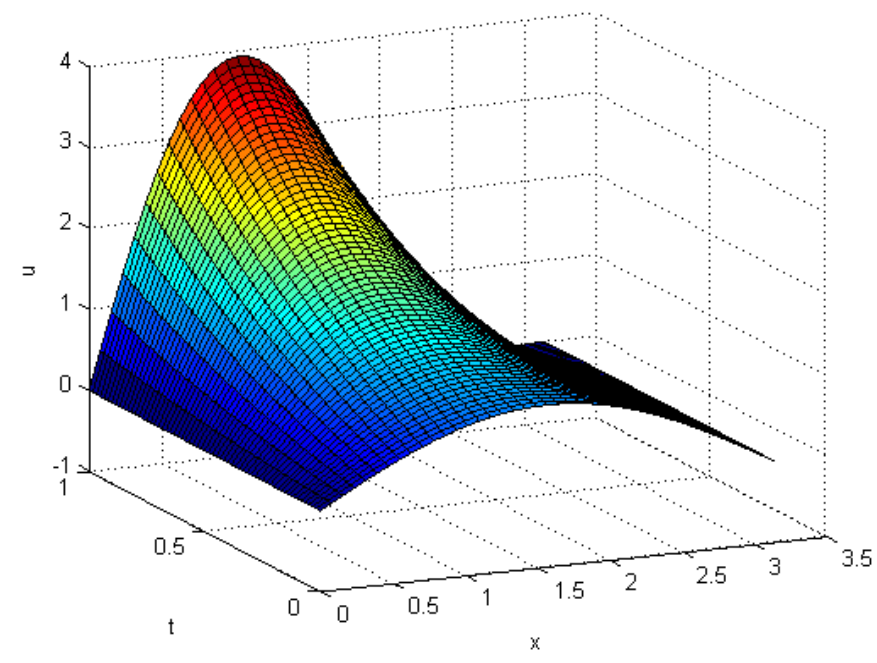

Fig. 2. The graph of problem solution from example 1

with parametres $\alpha=-1, \beta=-1, \lambda=-2, \lambda^{\prime}=-1, \lambda^{\prime \prime}=3$. This mathematical model is non-degenerate, therefore the solution exists. The graph of solution is shown on fig. 3 .

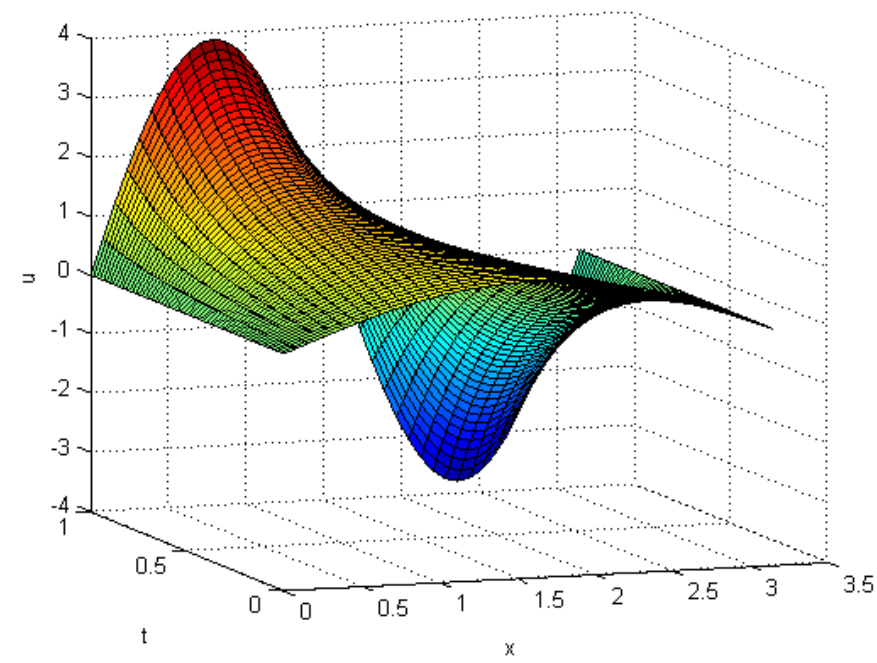

Fig. 3. The graph of problem solution from example 2

Example 3. Consider the mathematical model

$$
\left\{\begin{array}{l}
(\lambda-\Delta) u_{t t}=\alpha\left(\Delta-\lambda^{\prime}\right) u_{t}+\beta\left(\Delta-\lambda^{\prime \prime}\right) u \\
u(x, 0)=\sin (x), u_{t}(x, 0)=\sin (x)+\sin (2 x), \\
u(0, t)=u(\pi, t)=0 .
\end{array}\right.
$$

with parametres $\alpha=-1, \beta=-1, \lambda=-4, \lambda^{\prime}=-1, \lambda^{\prime \prime}=3$. As $\lambda=\lambda_{2}$ (it is coincide with the second eigenvalue of Laplace operator), the solution doesn't exist because the 
conditions of consistency[6]:

$$
\frac{1}{\mu_{k}} \int_{0}^{\pi} \psi(x) \cdot \varphi_{k}(x) d x=\int_{0}^{\pi} \varphi(x) \cdot \varphi_{k}(x) d x
$$

doesn't hold. The program gives the message about non-existence of solution shown on fig. 4 .

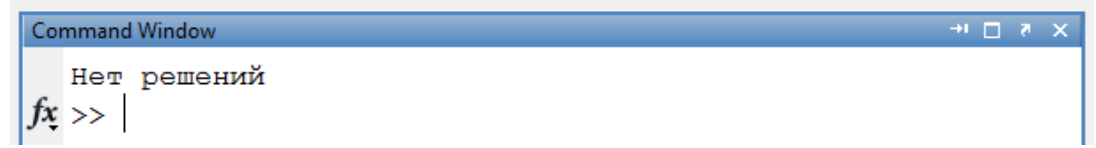

Fig. 4. Message about non-existence of solution in example 3

Example 4. Consider the mathematical model

$$
\left\{\begin{array}{l}
(\lambda-\Delta) u_{t t}=\alpha\left(\Delta-\lambda^{\prime}\right) u_{t}+\beta\left(\Delta-\lambda^{\prime \prime}\right) u, \\
u(x, 0)=\sin (x), u_{t}(x, 0)=\sin (x)+\sin (2 x), \\
u(0, t)=u(\pi, t)=0 .
\end{array}\right.
$$

with parametres $\alpha=-1, \beta=-1, \lambda=-1, \lambda^{\prime}=-1, \lambda^{\prime \prime}=3$. As $\lambda=\lambda^{\prime}=\lambda_{1}$ (coincide with the first eigenvalue of Laplace operator), then for existence of the solution it is necessary that initial functions belong to the phase space of equation, i.e. the following conditions must be satisfied [6]:

$$
\int_{0}^{\pi} \psi(x) \cdot \varphi_{k}(x) d x=0 \text { and } \int_{0}^{\pi} \varphi(x) \cdot \varphi_{k}(x) d x=0 .
$$

Obviously they is don't hold. The program gives the message about non-existence of solution shown on fig. 5 .

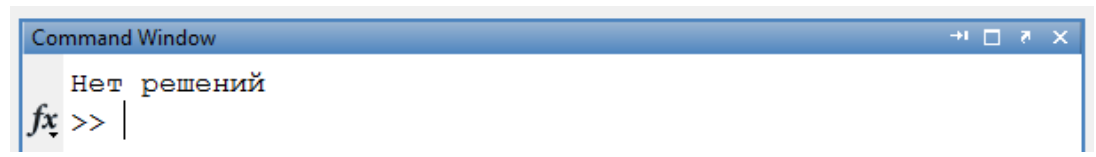

Fig. 5. Message about non-existence of solution in example 4

Example 5. Consider the mathematical model

$$
\left\{\begin{array}{l}
(\lambda-\Delta) u_{t t}=\alpha\left(\Delta-\lambda^{\prime}\right) u_{t}+\beta\left(\Delta-\lambda^{\prime \prime}\right) u, \\
u(x, 0)=\sin (3 x), u_{t}(x, 0)=\sin (2 x)+\sin (3 x), \\
u(0, t)=u(\pi, t)=0,
\end{array}\right.
$$

with parametres $\alpha=-1, \beta=-1, \lambda=-1, \lambda^{\prime}=-1, \lambda^{\prime \prime}=3$. As $\lambda=\lambda^{\prime}=\lambda_{1}$ (coincide with the first eigenvalue of Laplace operator), then for existence of the solution it is necessary that initial functions belong to the phase space of equation, i.e. the following conditions must be satisfied [6]:

$$
\int_{0}^{\pi} \psi(x) \cdot \varphi_{k}(x) d x=0 \text { and } \int_{0}^{\pi} \varphi(x) \cdot \varphi_{k}(x) d x=0
$$

Obviously they hold. The graph of solution is shown on fig. 6 . 


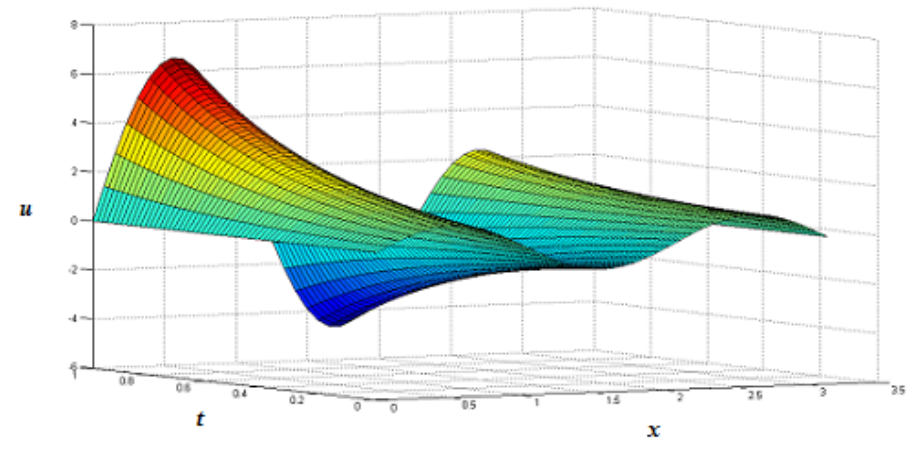

Fig. 6. The graph of problem solution from example 5

\section{References}

1. Lòve A. A Treatise on the Mathematical Theory of Elasticity. Moscow, Leningrad, ONTI, 1935. (in Russian)

2. Zamyshlyaeva A.A. The Higher-Order Sobolev-Type Models. Bulletin of the South Ural State University. Series: Mathematical Modelling, Programming and Computer Software, 2011, no. 7, p. 5-28. (in Russian)

3. Zamyshlyaeva A.A., Bychkov E.V. The Phase Space of the Modified Boussinesq Equation. Bulletin of the South Ural State University. Series: Mathematical Modelling, Programming and Computer Software, 2012, no. 18 (277), issue 12, pp. 13-19. (in Russian)

4. Zamyshlyaeva A.A., Yuzeeva A.V. The Initial-Finish Value Problem for the Boussinesq - Love Equation. Bulletin of the South Ural State University. Series: Mathematical Modelling, Programming and Computer Software, 2010, no. 16 (192), issue 5, pp. 23-31. (in Russian)

5. Zamyshlyaeva A.A., Tsyplenkova O.N. The Optimal Control over Solutions of the Initial-finish Value Problem for the Boussinesq - Love Equation. Bulletin of the South Ural State University. Series: Mathematical Modelling, Programming and Computer Software, 2012, no. 5 (264), issue 11, pp. 13-24. (in Russian)

6. Zamyshlyaeva A.A., Muravyev A.S. Study of the Mathematical Model BoussinesqLove. Vestnik Magnitogorskogo gosudarstvennogo universiteta. Seriya: Mathematika [Bulletin of Magnitogorsk State University. Series: Mathematics], 2013, issue 15, pp. 24-34. (in Russian)

7. Sviridyuk G.A., Sukacheva T.G. [Phase Spaces of One Class of Semilinear Equations of Sobolev Type]. Differentsial'nyie uravneniia [Differential Equations], 1990, vol. 26, no. 2, p. 250-258. (in Russian)

Zamyshlyaeva Alyona Aleksandrovna, doctor of physical and mathematical sciences, associate professor, professor of the department of equations of mathematical physics, South Ural State University, Chelyabinsk, Russian Federation, alzama@mail.ru. 
Surovtsev Sergey Viktorovich, master student, department of equation of mathematical physics, South Ural State University, Chelyabinsk, Russian Federation, ssw-92@ya.ru.

Received August 20, 2015

УДК 517.9

DOI: $10.14529 /$ jcem 150308

\title{
ЧИСЛЕННОЕ ИССЛЕДОВАНИЕ ОДНОЙ МАТЕМАТИЧЕСКОЙ МОДЕЛИ СОБОЛЕВСКОГО ТИПА
}

\author{
А.А. Замышляева, С.В. Суровцев
}

\begin{abstract}
Статья посвящена численному исследованию математической модели Буссинеска - Лява. На основе метода фазового пространства и применения метода конечных разностей построен алгоритм нахождения численного решения задачи Коши - Дирихле для уравнения Буссинеска - Лява, моделирующей продольные колебания в тонком упругом стержне с учетом поперечной инерции. Данная задача может быть редуцирована к задаче Коши для уравнения соболевского типа второго порядка, которая, как известно разрешима не при всех начальных значениях. Разработанный алгоритм содержит предварительную проверку принадлежности начальных данньг фазовому пространству. Алгоритм реализован в виде программы в среде Matlab. Приведены результаты вычислительных экспериментов в регулярном и вырожденном случаях. Представлены графики полученных решений.

Ключевые слова: уравнение Буссинеска - Ллва; задача Коши - Дирихле; метод конечных разностей; уравнение соболевского типа; фазовое пространство; условия согласования; система разностных уравнений; метод прогонки.
\end{abstract}

\section{Литература}

1. Ляв, А. Математическая теория упругости / А. Ляв. - Москва; Ленинград: ОНТИ, 1935.

2. Замышляева, А.А. Математические модели соболевского типа высокого порядка / А.А. Замышляева // Вестник ЮУрГУ. Серия: Математическое моделирование и программирование. - 2014. - Т. 7, № 2. - С. 5-28.

3. Замышляева, А.А. Фазовое пространство модифицированного уравнения Буссинеска / А.А. Замышляева, Е.В. Бычков // Вестник ЮУрГУ. Серия: Математическое моделирование и программирование. - 2012.- № 18 (277), вып. 12. - С. 13-19.

4. Замышляева, А.А. Начально-конечная задача для уравнения Буссинеска - Лява / А.А. Замышляева, А.В. Юзеева // Вестник ЮУрГУ. Серия: Математическое моделирование и программирование. - 2010. - № 16 (192), вып. 5. - С. 23-31.

5. Замышляева, А.А. Оптимальное управление решениями начально-конечной задачи для уравнения Буссинеска - Лява / А.А. Замышляева, О.Н. Цыпленкова // Вестник ЮУрГУ. Серия: Математическое моделирование и программирование. - 2012.- № 5 (264), вып. 11. - С. 13-24.

6. Замышляева, А.А. Исследование математической модели Буссинеска - Лява / А.А. Замышляева, А.С. Муравьев // Вестник Магнитогорского государственного университета. Серия: Математика. - 2013. - Вып. 15. - С. 24-34. 
7. Свиридюк, Г.А. Фазовые пространства одного класса операторных полулинейных уравнений типа Соболева / Г.А. Свиридюк, Т.Г. Сукачева // Дифференциальные уравнения. - 1990.- Т. 26, № 2. - С. 250-258.

Замыиляева Алена Александровна, доктор физико-математических наук, доцент, профессор кафедры уравнений математической физики, Южно-Уральский государственный университет (г. Челябинск, Российская Федерация), alzaта@таil.ru.

Суровиев Сергей Викторович, магистрант, кафедра уравнений математической физики, Южно-Уральский государственный университет (е. Челябинск, Российская Федерачия),ssw-92@yа.ru.

Поступила в редакиию 20 августа 2015 г. 